\title{
KARAKTERISASI KOLAGEN LARUT ASAM DARI KULIT IKAN TUNA (THUNNUS albacores.) DENGAN METODE HIDROEKSTRAKSI
}

\section{THE CHARACTERIZATION OF COLLAGEN ACID SOLUBLE FROM YELLOW FIN TUNA (THUNNUS albacores.) FISH SKIN BY USING HYDROECTRACTION METHOD}

\author{
Joice Patrecia M. Kolanus, Sugeng Hadinoto, Syarifuddin Idrus \\ Balai Riset dan Standardisasi Industri Ambon \\ Jl.Kebun Cengkeh Ambon 97128 \\ Email : joicekolanus@gmail.com
}

Diterima : 19-03-2019

Direvisi : 11-04-2019

Disetujui : 23-05-2019

\begin{abstract}
ABSTRAK
Kolagen merupakan produk yang banyak diperlukan dalam berbagai industri, baik industri pangan maupun non pangan namun sampai saat ini masih impor dari negara lain. Untuk memenuhi kolagen dalam negeri maka sudah dilakukan penelitian tentang sumber-sumber kolagen halal terutama dari limbah perikanan. Penelitian ini bertujuan untuk mengekstrak kolagen dari limbah kulit ikan tuna (Thunnus albacore.) dengan variasi konsentrasi pelarut asam asetat dan metode hidroekstraksi. Pembuatan kolagen dari kulit ikan tuna dilakukan dengan metode asam alkali melalui perendaman dalam asam asetat konsentrasi 0,05 M dan 0,1 M selama 2 jam dan metode hidroekstraksi suhu $40^{\circ} \mathrm{C}$ selama 1 jam. Sifat-sifat kolagen yang diamati yaitu rendemen, gugus fungsi dan komposisi asam amino. Hasil penelitian menunjukkan bahwa metode hidroekstraksi dengan pengesktrak asam asetat 0,05 $\mathrm{M}$ dan 0,1 M memiliki rendemen berturut turut sebesar 1,95\% dan 2,57\&. Kolagen teridentifikasi dari gugus fungsi amida A, amida B, amida I, amida II dan amida III. Kadar asam amino dengan komposisi tertinggi yaitu asam glutamat, glisin, alanin, arginin dan prolin.
\end{abstract}

Kata kunci : kolagen,kulit ikan tuna,hidroekstraksi

\begin{abstract}
Collagen is a product that is widely needed in various industries, both food and non-food industries, But until now it is still imported from other countries. To meet domestic collagen, research has been conducted on sources of halal collagen, especially from fisheries waste. This study aims to extract collagen from tuna skin waste (Thunnus albacore.) With variations in the concentration of acetic acid solvents and hydro-extraction methods. Making collagen from tuna skin is done by acid alkali method through immersion in acetic acid concentrations of $0.05 \mathrm{M}$ and $0.1 \mathrm{M}$ for 2 hours and the hydroelectric method of $400 \mathrm{C}$ for 1 hour. The properties of collagen were observed namely yield, functional group and amino acid composition. The results showed that the hydro-extraction method with $0.05 \mathrm{M}$ and 0.1 $M$ acetic acid extraction had a yield of $1.95 \%$ and 2.57 \& respectively. Collagen was identified from the functional groups amide $A$, amide B, amide I, amide II and amide III. Amino acid levels with the highest composition are glutamic acid, glycine, alanine, arginine and proline.
\end{abstract}

Keywords : collagen, tuna skin, hydro-extraction 


\section{PENDAHULUAN}

$\mathrm{K}$ olagen merupakan produk yang banyak diperlukan dalam berbagai industri, baik, industri makanan, industri farmasi, industri kosmetik juga digunakan untuk kepentingan biomedis dan farmasetika. (Nurilmala dkk, 2017: 1). Produksi kolagen dalam negeri sendiri sampai saat ini masih belum optimal. Pada Tahun 2003, Indonesia masih mengimpor lebih dari 6200 ton kolagen dengan harga per gram mencapai kurang lebih US\$1. Kebutuhan kolagen di Indonesia terpenuhi dengan cara mengimpor dari berbagai negara seperti Perancis, Jerman, Jepang dan India (Tridhar N.A, 2016: 3). Data International Trade Center (2016) menyebutkan bahwa impor gelatin termasuk kolagen ke Indonesia dengan HS Code 3503 pada Tahun 2015 adalah 4.109 ton dengan nilai mencapai US\$ 31.741.000. (Fawzya, Y.N, dkk., 2016: 2). Untuk itu diperlukan pengembangan industri dalam negeri untuk memproduksi kolagen dan mengatasi masalah impor.

Kolagen merupakan komponen struktural utama jaringan ikat putih (white connective tissue) yakni sekitar 25 - 30\% (Walter dan Stegemann (2014) dalam Kartika I.W dkk (2016: 223). Protein kasar kulit dapat menggambarkan kemungkinan maksimum komponen kolagen yang dapat diekstraksi. Kittiphattanabawon et al. (2010: 793) menyatakan bahwa sumber kolagen alternatif dapat berasal dari kulit dan bagian tulang ikan yang merupakan limbah dari hasil pengolahan. Kulit ikan memiliki protein struktural yang kompleks untuk mempertahankan kekuatan fleksibilitas kulit, ligamen, tulang, sendi, otot, tendon, gusi, mata, pembuluh darah, kuku, dan rambut. Kandungan protein ikan adalah lebih dari $90 \%$ dan memiliki 18 jenis asam amino yang $7 \mathrm{di}$ antaranya penting untuk konsumsi manusia. Produk kolagen bahan ini mudah diserap dan memiliki nilai biologis tinggi yang mendorong penyerapan vitamin dan mineral (Kumar M.H et al., 2011: 97).

Menurut Nagai dan Suzuki, (2000) dan Sato, et al., (1989) dalam Nurhayati dkk., (2013: 86) menyatakan bahwa tipe kolagen yang teridentifikasi pada ikan hanya tipe I dan V. Kolagen tipe I terdapat pada kulit, tulang dan sisik ikan, sedangkan kolagen tipe $\mathrm{V}$ terdapat pada jaringan ikat dalam kulit, tendon, dan otot ikan yang juga mengandung kolagen tipe I.

Menurut Wang, W et al. (2013: 1), penelitian tentang hidrolisis kolagen yang berasal dari ikan banyak digunakan di berbagai bidang termasuk makanan fungsional, minuman, dan suplemen makanan yang menunjukkan bahwa sifat fungsional tesebut dibutuhkan dalam makanan. Penelitian-peelitian tersebut diantaranya adalah hidrolisis kolagen yang berasal dari ikan untuk meningkatkan metabolisme tulang (Guillerminetet al. 2010); untuk mencegah penuaan kulit (Tanaka et al. 2009); optimalisasi proses produksi kolagen hidrolisat kulit dengan sifat antioksidan (Yang et al. (2009); protein hidrolisat dari kulit nila dihidrolisis dengan enzim protease (Wasswaet al. (2008).

Limbah ikan terdiri dari tulang, kulit, sirip, kepala, sisik dan jeroan. Limbah ikan ini merupakan salah satu permasalahan terbesar dalam industri pengolahan ikan karena dapat menyebabkan masalah lingkungan disebabkan karena limbah ini biasanya belum diolah secara baik. Diketahui bahwa limbah industri pembekuan dan pengalengan ikan tuna berpotensi sebagai sumber kolagen yang halal, salah satunya adalah bagian kulit. Mayasari (2016: 1) menyatakan bahwa kulit ikan tuna (Thunnus albacares) termasuk kulit berprotein tinggi sehingga berpotensi untuk dijadikan sumber kolagen. Menurut Chen et al (2016) dalam Nurilmala et al (2017: 340), kulit dan sisik memiliki kandungan kolagen yang lebih tinggi dibandingkan pada bagian tulang. Menurut Kolodziejska et al. (2008) dalam Devi (2017: 258) menyatakan bahwa kulit ikan merupakan bahan baku yang baik untuk mengisolasi kolagen karena kolagen merupakan penyusun $80 \%$ protein yang terdapat pada kulit ikan.

Menurut Wulandari (2016: 1) menyatakan bahwa isolasi kolagen dari limbah produk perairan telah banyak dilakukan, baik di Indonesia maupun di luar negeri. Di Indonesia, isolasi kolagen telah dilakukan pada kulit ikan pari (Nur'aenah, 2013); kulit ikan buntal pisang (Faisal, 
2014), kulit ikan ekor kuning (Astiana., dkk., 2016); kulit ikan tuna (Thunnus sp.) (Mayasari, 2016), kulit dan tulang ikan cakalang (Stephani dkk, 2016); gelembung renang ikan cunang (Djailani, 2016); sedangkan kolagen yang diisolasi dari luar negeri di antaranya dari kulit ikan karper rumput (Liu et al., 2015a), kulit, sisik dan gelembung renang ikan karper rumput (Liu et al. 2015b), sisik ikan mata merah (Chen et al., 2016); sisik ikan nila (Huang et al. 2016); sedangkan menurut Devi, dkk (2017: 256) menyatakan bahwa kolagen yang diekstrak dari ikan air laut antara lain dari tulang rawan ikan hiu Chiloscyllium punctatum dan Blacktip (Kittiphattanabawon et al. 2010), abalone (Dong et al. 2012), dan kulit ikan tuna (Hema et al. 2013).

Kulit ikan tuna dilaporkan mengandung kolagen dengan nilai rendemen yang bervariasi antara 11 - 63\% tergantung dari jenis ikan, bahan pengekstrak dan teknik ekstraksi kolagen (Nagai \& Suzuki, 2000 dalam Nurhayati, dkk (2013: 86).

Proses hidrolisis atau isolasi kolagen menggunakan beberapa teknik. Teknik isolasi kulit ikan umumnya diekstraksi dengan metode asam (ASC), alkali dan enzim (PSC). Teknik ini mampu menghasilkan kolagen dengan tingkat kemurnian yang tinggi namun memerlukan waktu lama, jumlah bahan kimia yang banyak dan biaya produksi yang tinggi sehingga menyebabkan kolagen yang dihasilkan tidak mampu berdaya saing dengan kolagen komersial.

Teknik lain yang dianggap memerlukan biaya produksi yang rendah dan mampu menghasilkan kolagen dengan waktu yang relatif cepat yaitu menggunakan metode hidrotermal atau hidroekstraksi. Teknik hidroekstraksi merupakan proses isolasi menggunakan air sebagai katalis dan temperatur sebagai tekanan. Jadi proses hidroekstraksi atau proses hidrotermal ini adalah proses ekstraksi yang melibatkan air dan tekanan suhu (high temperature short time/HTST) dengan akuades sebagai media pindah panas.

Wulandari (2016: 30) mengisolasi kolagen dari kulit ikan gabus menggunakan metode hidroekstraksi menghasilkan rendemen sebesar $16 \%$ (bb), komposisi asam amino yang dominan yaitu glisina $27,11 \%$, prolina $13,87 \%$ dan alanina $12,58 \%$ dan merupakan kolagen tipe I dicirikan dengan adanya rantai a1 dan a2. Djailani dkk. (2016: 156) menyatakan mengekstraksi kolagen dari gelembung renang ikan cunang menggunakan kombinasi metode ASC dan hidroekstraksi menghasilkan kolagen tipe I dengan rendemen sebesar $63,35 \%$.

Pemanfaatan limbah kulit ikan tuna sebagai kolagen sangat penting untuk dikembangkan karena limbah kulit ikan ini selain menjadi sumber kolagen juga mendorong pemanfaatan bahan alam sehingga dapat menerapkan efektivitas bahan, mengurangi pencemaran lingkungan, menerapkan pengolahan bersih (cleaner production) serta meningkatkan nilai jual kulit ikan dari sekedar limbah menjadi bahan yang bernilai lebih. Kelebihan lain pembuatan kolagen dengan bahan baku kulit dibandingkan dengan bahan baku dari tulang dan sisik yaitu membutuhkan waktu proses lebih cepat dengan proses perendaman asam. Disamping itu kulit ikan memiliki tekstur yang lebih lunak dibandingkan dengan tulang sehingga membutuhkan waktu proses ekstraksi yang lebih cepat. Oleh karena itu penting dilakukan penelitian pengembangan produk kolagen dari kulit ikan tuna.

Pemahaman tentang sifat-sifat kolagen dan mikroskopis kulit ikan tuna menjadi hal yang penting karena dapat dijadikan sebagai alternatif kolagen komersial yang halal. Kolagen dapat diekstrak dan diisolasi dengan beberapa metode atau proses, namun hingga kini metode ekstraksi asam masih mendominasi karena cukup mudah dilakukan. Proses isolasi kolagen dengan beberapa proses ekstraksi sangat mempengaruhi rendemen dan karakteristik kolagen yang dihasilkan, sehingga penelitian tentang proses isolasi dan karakterisasi kolagen melalui beberapa modifikasi proses ekstraksi perlu dilakukan untuk memperoleh kualitas dan kuantitas kolagen yang maksimal. Pada penelitian ini produksi kolagen dari kulit ikan tuna (Thunnus albacore) menggunakan metode hidroekstraksi agar supaya dapat menghemat biaya produksi sehingga dapat diterapkan di masyarakat. Namun perlu untuk mengetahui komposisi 
penyusun kolagen dengan menggunakan metode hidroekstraksi ini. Oleh karena itu penelitian karakterisasi kolagen larut asam dari kulit ikan tuna (Thunnus albacore) dengan metode hidroekstraksi bertujuan untuk melakukan ekstraksi kolagen kulit ikan tuna (Thunnus albacore) dengan variasi konsentrasi pelarut asam asetat dan metode hidroekstraksi. Penelitian yang digunakan adalah penelitian deskriptif kuantitatif dengan pendekatan eksperimen laboratorium.

Manfaat dari penelitian ini diharapkan dapat meningkatkan nilai ekonomis limbah industri pembekuan dan pengalengan ikan tuna, dalam hal ini bagian kulit ikan tuna serta memperoleh sumber bahan baku kolagen dari limbah perikanan. Sedangkan dampaknya yaitu dapat mengurangi ketergantungan akan produk impor kolagen.

\section{METODE PENELITIAN}

\section{Bahan dan Alat}

Bahan utama yang digunakan dalam penelitian ini adalah limbah kulit ikan tuna (Thunnus albacares) yang diperoleh dari limbah industri pembekuan ikan PT. AKFI yang berada di desa Laha, Teluk Ambon. Kulit ikan dibawa dengan cool box yang sudah diberi es. Dicuci bersih dan dipotong-potong dengan ukuran kira-kira 0,5 x 0,5 $\mathrm{cm}^{2}$ dan disimpan pada suhu beku sampai kulit digunakan untuk tahap ekstraksi. Bahan lain yang digunakan antara lain : Aquades, $\mathrm{NaOH}, \mathrm{CH}_{3} \mathrm{COOH}, \mathrm{BSA}$. Sedangkan peralatan yang digunakan antara lain : neraca analitik, pH meter, gunting bedah, gelas ukur, pipet, waterbath incubator shaker, magnetic stirrer ukuran $5 \mathrm{~cm}$, rotary evaporator, instrumen HPLC, FIIR dan freeze dryer.

\section{Metode \\ Prosedur Kerja :}

Preparasi sampel. Sampel yang digunakan merupakan limbah kulit ikan tuna yang diambil dari perusahaan pembekuan ikan PT. AKFI. Sampel kulit dibersihkan dari sisik dan daging yang masih menempel kemudian dicuci dengan air bersih. Selanjutnya dipotong menjadi ukuran kecil sekitar 2-3 cm. Setelah itu, dicuci kembali dan ditiriskan untuk menghilangkan air sisa pencucian.

Proses ekstraksi kolagen menggunakan metode hidroekstraksi mengacu pada modifikasi Liu et al. 2015 dalam Wulandari (2016: 17). Proses ekstraksi kolagen terdiri 3 tahap yaitu pretreatment dengan larutan $\mathrm{NaOH}$, hidrolisis dalam larutan asam asetat, dan ekstraksi.

Tahap pertama yaitu proses pretreatment dengan larutan $\mathrm{NaOH}$ bertujuan untuk mengeliminasi non kolagen dan pengotor lainnya seperti lemak, mineral, pigmen dan odor (degreasing). Kulit ikan tuna (Thunus albacore.) direndam dalam larutan $\mathrm{NaOH}$ dengan konsentrasi 0,2 M selama 12 jam perendaman dan setiap 2 jam sekali larutan $\mathrm{NaOH}$ diganti. Rasio antara kulit dan larutan $\mathrm{NaOH}$ adalah 1:10 (b/v). Selanjutnya dinetralisasi dengan aquades sebelum digunakan untuk tahap selanjutnya.

Tahap kedua adalah hidrolisis dengan larutan asam asetat $\left(\mathrm{CH}_{3} \mathrm{COOH}\right)$ bertujuan untuk mengubah struktur serat kolagen sehingga mempermudah proses ekstraksi. Perlakuan konsentrasi asam asetat yang digunakan yaitu 0,05 $\mathrm{M}$ dan 0,1 $\mathrm{M}$ dan direndam selama 2 jam. Rasio antara kulit dan asam asetat adalah 1:10 (b/v). Hasil perendaman asam asetat kemudian dinetralkan dengan aquades hingga mencapai $\mathrm{pH}$ netral sebelum digunakan untuk ekstraksi. Tahap ketiga yaitu ekstraksi. Hidroekstraksi dengan aquadest rasio $1: 2$ (b/v) pada suhu $40^{\circ} \mathrm{C}$ selama 1 jam menggunakan waterbath shaker kecepatan $150 \mathrm{rpm}$. Hasil ekstraksi ini disaring dengan dua lapis kain katun tipis untuk mendapatkan filtrat. Selanjutnya filtrat disentrifus untuk memisahkan lemak dengan protein hidroksiprolin. Filtrat hasil sentrifus 
dikeringkan menggunakan freeze drying sehingga berbentuk bubuk. Bubuk kolagen ini siap untuk dilakukan analisa terhadap gugus fungsi dan asam amino.

\section{Metode Analisis \\ Rendemen}

Perhitungan rendemen kolagen basis kering yaitu dihitung berdasarkan persentase perbandingan berat kering kolagen dengan berat basah bahan baku kulit mentah sebelum ekstraksi. Rendemen menunjukkan keefektifan proses ekstraksi (Alhana dkk. 2015:155).

\section{Analisis Gugus Fungsi dengan FTIR (Modifikasi Yan et al.2008 dalam Djailani, 2016)}

Karakterisasi gugus fungsi kolagen untuk mengetahui gugus-gugus fungsi khas dari kolagen yang dihasilkan. Analisis menggunakan FT-IR (Fourier Transform Infra-Red). Gugusgugus fungsi yang diperlihatkan pada spektrum kolagen digunakan untuk menentukan pola ikatan silang (cross-linking) yang terjadi sehingga perubahan pada stuktur sekunder kolagen dapat dipelajari. Sampel uji terlebih dahulu dibentuk pellet dengan campuran $\mathrm{KBr}$. Sebanyak $100 \mathrm{mg} \mathrm{KBr}$ dan $2 \mathrm{mg}$ sampel uji dicampurkan, kemudian ditumbuk sampai halus dan tercampur rata dalam mortaragate. Pengukuran sampel uji dilakukan pada gelombang antara $4000-5000 \mathrm{~cm}^{-1}$. Spektra FTIR yang dihasilkan menunjukkan puncak-puncak serapan bilangan gelombang dari sampel uji. Gugus-gugus fungsi sampel uji ditentukan berdasarkan puncak serapan bilangan gelombang yang terdeteksi dengan wilayah serapan untuk gugus fungsi protein.

\section{Analisis Asam Amino (AOAC, 2012)}

Untuk mengetahui Komposisi asam amino dari kolagen kulit ikan tuna digunakan instrumen HPLC (High Pefformance Liquid Chromatography). Perangkat HPLC dibilas dahulu dengan eluen yang akan digunakan selama 2-3 jam. Syringe yang akan digunakan juga harus dibilas dengan aquades. Analisis asam amino menggunakan HPLC terdiri atas 4 tahap, yaitu (1) pembuatan hidrolisat protein; (2) pengeringan; (3) derivatisasi; dan (4) injeksi serta analisis asam amino. Khusus untuk pengujian asam amino bebas, tidak dilakukan proses hidrolisis dengan asam dan pemanasan.

\section{a. Tahap Pembuatan hidrolisat protein}

Sampel ditimbang sebanyak 0,2 $\mathrm{g}$ dan dihancurkan. Sampel yang telah hancur ditambahkan dengan $\mathrm{HCl} 6 \mathrm{~N}$ sebanyak $5-510 \mathrm{ml}$, kemudian dipanaskan dalam oven pada suhu $100^{\circ} \mathrm{C}$ selama 24 jam. Proses pemanasan dilakukan untuk menghilangkan gas atau udara yang ada pada sampel agar tidak mengganggu kromatogram yang dihasilkan dan untuk mempercepat reaksi hidrolisis. Hidrolisat protein yang diperoleh disaring dengan milipore berukuran 0,45 mikron.

\section{b. Tahap pengeringan}

Hidrolisat protein ditambah dengan $30 \mu \mathrm{L}$ larutan pengering. Larutan pengering dibuat dari campuran antara metanol, natrium asetat, dan trietilamin dengan perbandingan 2 : 2 : 1. Proses pengeringan dibantu menggunakan gas nitrogen untuk mempercepat pengeringan dan mencegah oksidasi.

\section{c. Tahap derivatisasi}

Sebanyak $30 \mu \mathrm{L}$ larutan derivatisasi ditambahkan pada hasil pengeringan. Larutan derivatisasi dibuat dari campuran antara larutan metanol, pikoiotisianat, dan trietilamin dengan perbandingan $3: 3: 4$. Proses derivatisasi dilakukan agar detektor mudah untuk mendeteksi 
senyawa yang ada pada sampel, kemudian dilakukan pengenceran dengan cara menambahkan $10 \mathrm{~mL}$ asetonitil $60 \%$ atau buffer fosfat $0.1 \mathrm{M}$ lalu dibiarkan selama 20 menit. Hasil pengenceran disaring kembali menggunakan milipor berukuran 0.45 mikron.

d. Injeksi ke HPLC

Hasil saringan diambil sebanyak $20 \mu \mathrm{L}$ untuk diinjeksikan ke dalam HPLC. Penghitungan konsentrasi asam amino dilakukan dengan cara membandingkan kromatogram sampel dengan standar. Pembuatan kromatogram standar menggunakan asam amino yang mengalami perlakuan yang sama dengan sampel.

Kandungan masing-masing asam amino pada bahan dapat dihitung dengan rumus :

$$
\begin{aligned}
& \text { Konsentrasi Asam Amino }=\frac{\text { Luas area contoh }}{\text { Luas area standar }} \times \frac{\mathrm{C} \times \mathrm{FP} \times \mathrm{BM} \times 100}{\text { berat contoh }(\mathrm{g})} \\
& \text { Keterangan: } \\
& \begin{array}{l}
\mathrm{C} \quad=\text { Konsentrasi standar asam amino } \\
\mathrm{FP} \quad=\text { Faktor pengenceran } \\
\mathrm{BM} \quad=\text { Bobot molekul dari masing-masing asam amino }
\end{array}
\end{aligned}
$$

\section{HASIL DAN PEMBAHASAN Rendemen}

Rendemen yang diperoleh dari pengolahan kolagen merupakan salah satu parameter penting dalam menilai tingkat efektivitas produksi kolagen yang melalui beberapa tahap seperti pemotongan kulit ikan, demineralisasi, hidrolisis dan ekstraksi hingga proses pengeringan. Semakin tinggi nilai rendemen suatu perlakuan, maka semakin tinggi tingkat efektifitas perlakuan tersebut (Maulida, 2011 dalam Samosir A.S dkk. (2018: 107). Rendemen kolagen yang diperoleh pada ekstraksi asam kombinasi metode hidroekstraksi dengan konsentrasi perendaman asam asetat $005 \mathrm{M}$ dan $0,1 \mathrm{M}$ berturut-turut adalah 1,95\% dan $2,57 \%$. Rendemen yang diperoleh tergolong kecil diakibatkan banyaknya kolagen yang terbuang pada saat proses pencucian mengakibatkan hilangnya massa kolagen dan kemungkinan juga diakibatkan dari proses hidrolisis dan ekstraksi yang kurang sempurna. Menurut Naro, A.B dkk. (2013: 172) menyatakan bahwa rendemen, karakter, dan komposisi molekul kolagen sangat dipengaruhi oleh perbedaan spesies, habitat dan perlakuan pada proses ekstraksi.

\section{Gugus fungsi Senyawa Kimia Pembentuk Kolagen}

Analisis FTIR dilakukan untuk memastikan senyawa yang dihasilkan merupakan kolagen berdasarkan gugus-gugus fungsi penyusunnya. Hasil analisis menunjukkan adanya puncak serapan amida A, amida B, amida I, amida II dan amida III (Gambar 1). Data sebaran amida kolagen kulit ikan tuna konsentrasi 0,05 $\mathrm{M}$ dan 0,1 $\mathrm{M}$ metode hidroekstraksi menunjukkan puncak serapan amida A, amida B, amida I, amida II dan III mengidentifikasikan struktur pada protein kolagen. Data sebaran amida kolagen kulit ikan tuna konsentrasi asam asetat 0,05 $\mathrm{M}$ dan 0,1 M metode hidroekstraksi ditampilkan pada Gambar. 1 


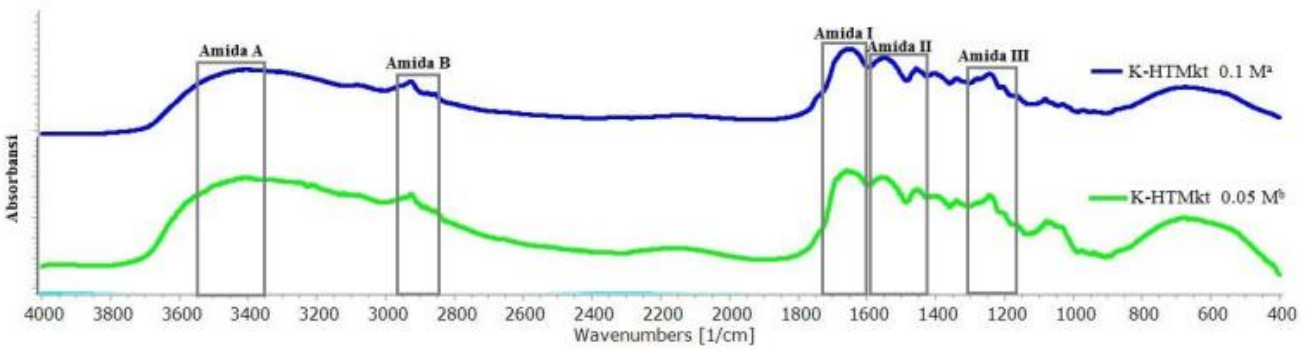

Gambar 1. Data Sebaran Amida Kolagen Kulit Ikan Tuna Konsentrasi 0,05 M Dan 0,1 M

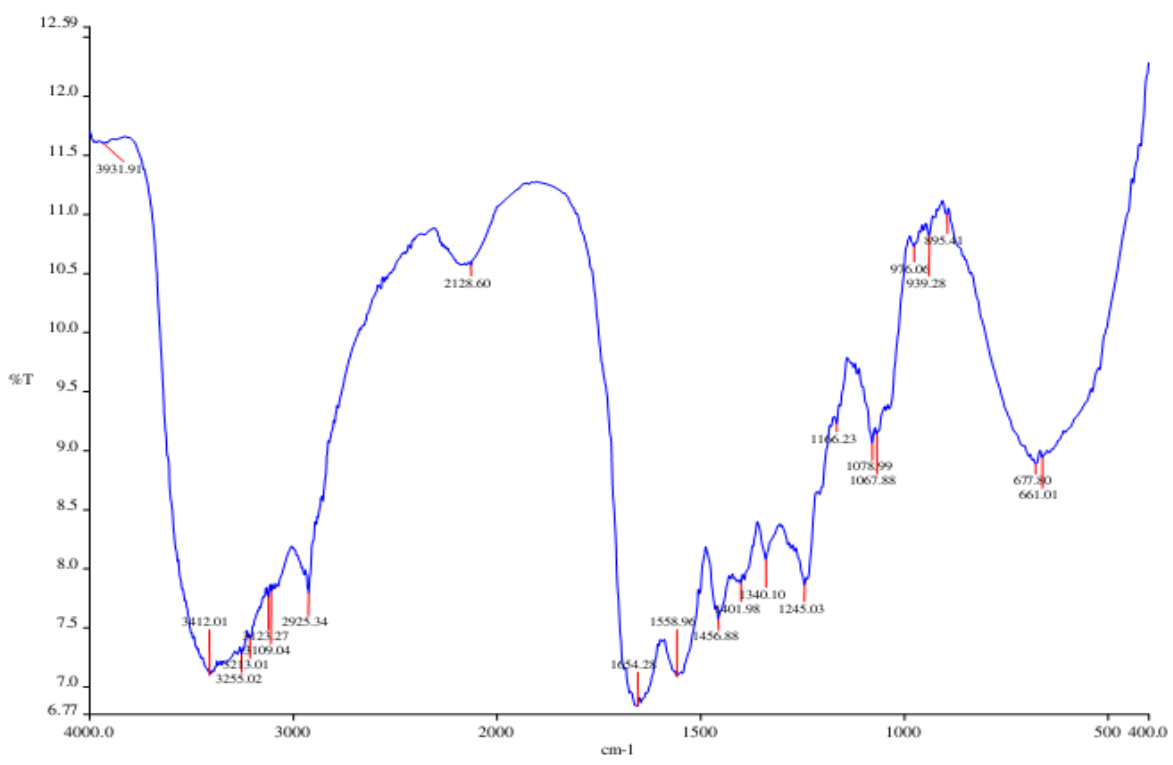

Gambar 2. Spektrum FT-IR Kolagen Kulit Ikan Tuna Konsentrasi 0,05 M

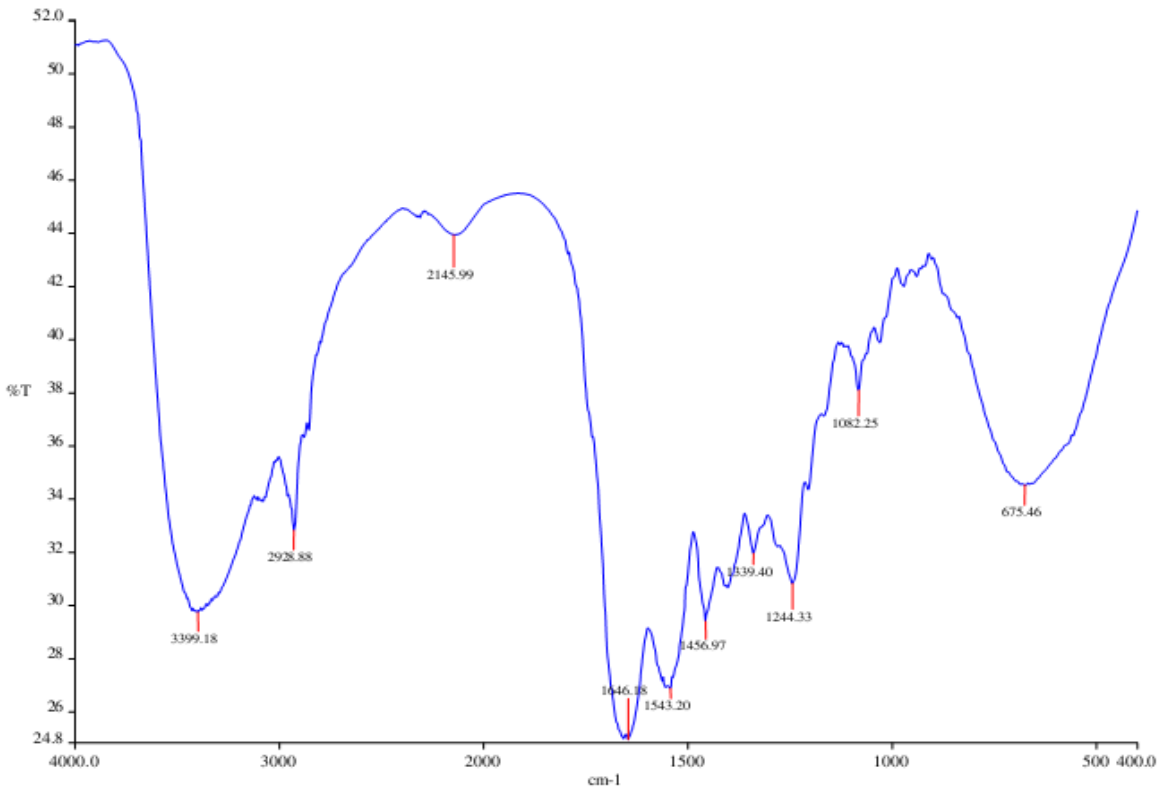

Gambar 3. Spektrum FT-IR Kolagen Kulit Ikan Tuna Konsentrasi 0,1 M 
Kolagen kulit ikan tuna konsentrasi 0,05 M dan 0,1 M metode hidroekstraksi memunculkan puncak serapan Amida A berturut-turut yakni 3412,01 dan 3399,18 cm${ }^{-1}$, amida B yaitu 2925,34 dan $2928,88 \mathrm{~cm}^{-1}$, Amida I yaitu 1654,28 dan 1646,18 cm $\mathrm{cm}^{-1}$, Amida II yaitu 1558,96 dan 1543,20 $\mathrm{cm}^{-1}$, Amida III yaitu 1245,03 dan $1244,33 \mathrm{~cm}^{-1}$.

Karakteristik gugus fungsi kolagen kulit ikan tuna dengan konsentrasi 0,05 $\mathrm{M}$ dan 0,1 $\mathrm{M}$ ditampilkan pada Tabel 1.

Tabel 1. Karakteristik Gugus Fungsi Kolagen Kulit Ikan Tuna Dengan Konsentrasi Pengekstrak Asam Asetat 0,05 M dan 0,1 M

\begin{tabular}{|c|c|c|c|c|}
\hline Amida & $\begin{array}{c}\text { Wilayah } \\
\text { puncak } \\
\text { serapan } \\
\left(\mathrm{cm}^{-1}\right)\end{array}$ & $\begin{array}{c}\text { Bilangan gelombang } \\
\text { puncak serapan }\left(\mathrm{cm}^{-}\right. \\
\text {1) } \\
\text { Puncak serapan } \\
\text { kolagen kulit ikan } \\
\text { tuna dengan } \\
\text { pengestrak asam } \\
\text { asetat } \\
0,05 \mathrm{M} \quad 0,1 \mathrm{M}\end{array}$ & Keterangan & Referensi \\
\hline
\end{tabular}

\begin{tabular}{|c|c|c|c|c|c|}
\hline Amida $\mathrm{A}$ & $\begin{array}{l}3315- \\
3440\end{array}$ & 3412,01 & 3399,18 & Gugus NH streching & J.Krishnamoorthi et al.(2017) \\
\hline Amida B & $\begin{array}{l}2925- \\
2935\end{array}$ & 2925,34 & 2928,88 & $\begin{array}{l}\text { Gugus } \mathrm{CH}_{2} \text { asymetrical } \\
\text { stretch }\end{array}$ & Muyonga et al.(2004)* \\
\hline Amida I & $\begin{array}{l}1600- \\
1660\end{array}$ & 1654,28 & 1646,18 & $\begin{array}{l}\text { Gugus Karbonil (ikatan } \\
\mathrm{C}=\mathrm{O} \text { ) stretching }\end{array}$ & J.Krishnamoorthi et al.(2017) \\
\hline Amida II & $\begin{array}{l}1550- \\
1600\end{array}$ & 1558,96 & 1543,20 & $\begin{array}{l}\mathrm{CN} \text { stretching } \mathrm{NH} \\
\text { bending }\end{array}$ & $\begin{array}{l}\text { Ahmad dan Benjakul (2010), } \\
\text { Duan et al. (2009)* }\end{array}$ \\
\hline Amida III & $\begin{array}{l}1220- \\
1320\end{array}$ & 1245,03 & 1244,33 & $\begin{array}{l}\text { Struktur unting ganda } \\
\text { tiga kolagen }\end{array}$ & $\begin{array}{l}\text { Benjakul et al. (2010), } \\
\text { Heuet al.(2010** }\end{array}$ \\
\hline
\end{tabular}

Berdasarkan Tabel 1 dan Gambar 2 dan 3, menunjukkan bahwa spektrum FT-IR kolagen kulit ikan tuna metode hidroekstraksi pada suhu ekstraksi $40^{\circ} \mathrm{C}$ dimulai pada $3412 \mathrm{~cm}^{-1}$ dan mengalami penurunan ke frekuensi yang lebih rendah menjadi $661 \mathrm{~cm}^{-1}$. Daerah serapan amida A, B, I, II, dan III untuk pengekstrak 0,05 M berada pada 3412, 2925, 1654, 1558, dan 1245 $\mathrm{cm}^{-1}$. Sedangkan untuk pengeskstrak 0,1 M berada pada 3399, 2928, 1646, 1543 dan $1244 \mathrm{~cm}^{-}$ 1. Amida A kolagen 0,05 M pada $3412 \mathrm{~cm}^{-1}$ sedangkan 0,1 M pada $3399 \mathrm{~cm}^{-1}$. Hal ini menunjukkan bahwa 0,1 M lebih banyak kelompok $\mathrm{NH}$ yang terlibat dalam ikatan hidrogen dibandingkan pada 0,05 M. Daerah serapan amida A pada kolagen terjadi karena regangan $\mathrm{NH}$ dari gugus amida dengan ikatan hidrogen dan asam amino hidroksiprolina.

Daerah serapan amida I,II dan III diketahui berhubungan langsung dengan bentuk polipeptida. Ikatan $\mathrm{N}-\mathrm{H}$ terjadi pada kisaran 3400-3440 $\mathrm{cm}^{-1}$. Ikatan $\mathrm{N}-\mathrm{H}$ (Amida A) pada kolagen yang diekstraksi pada suhu $40^{\circ} \mathrm{C}$ mengalami penurunan ke frekuensi yang lebih rendah. Amida A dari kolagen metode hidroekstraksi pengekstrak asam asetat 0,05M dan 0,1M kulit ikan tuna mengalami penurunan amplitudo pada $3300 \mathrm{~cm}^{-1}$. Puncak serapan amida B yang diimiliki 
kolagen kulit ikan tuna terdeteksi pada bilangan gelombang kisaran 2925,34 dan 2928,88 cm-1 yang mengindikasikan adanya gugus khas kolagen yaitu amida B. Coates (2000) dalam Mayasari (2016: 14), bilangan gelombang yang mengindikasikan serapan amida $B$ terbentuk dari gugus $\mathrm{CH}_{2}$ asymmetrical stretch. Puncak serapan Amida I kolagen kulit ikan tuna pada suhu ekstraksi $40^{\circ} \mathrm{C}$ menunjukkan nilai $1654,28 \mathrm{~cm}^{-1}$ dan $1646,18 \mathrm{~cm}^{-}$. Singh et al. (2011) dalam Devi dkk (2017: 261) menyatakan bahwa nilai amida I yang rendah dikarenakan besarnya porsi nonheliks pada telopeptida sehingga ikatan intramolekuler hidrogen antara $\mathrm{C}=\mathrm{O}$ pada peptida dan keterkaitan donor hidrogen lebih rendah. Amida I dihubungkan dengan adanya peregangan gugus karbonil ikatan $\mathrm{C}=\mathrm{O}$ sepanjang polipeptida dengan kontribusi ikatan $\mathrm{NH}$ dan renggangan $\mathrm{CN}$ dan menjadi faktor penting dalam perannya untuk mengetahui struktur sekunder dari protein. Amida I terdiri dari empat komponen struktur sekunder protein yaitu a-helix, $\beta$-sheet, $\beta$-turn dan random coil yang saling bertumpang tindih. Amida II berhubungan langsung dengan $\mathrm{CN}$ stretching dan $\mathrm{NH}$ bending. yang berada dalam wilayah serapan $1550-1600 \mathrm{~cm}^{-1}$. Puncak serapan amida II pada kolagen kulit ikan tuna $0,05 \mathrm{M}$ dan $0,1 \mathrm{M}$ pada suhu $40^{\circ} \mathrm{C}$ berada pada wilayah serapan berturut-turut 1558,96 cm-1 dan 1543,20 cm-1.

Muyonga et al. (2004) dalam Gadi dkk (2017: 675) menyatakan bahwa amida I memiliki empat komponen struktur sekunder protein, yaitu a-heliks, $\beta$-sheet, $\beta$-turn, dan random coil yang saling bertumpang tindih. Hal ini menunjukkan bahwa kolagen dari kulit ikan tuna memiliki struktur $\beta$-sheet belum terdenaturasi menjadi a-helix ciri khas gelatin.

Stabilitas triple helix dalam kolagen tergantung pada ikatan hidrogen (Krishnamoorthia J., et al. (2017: 39)

\section{Analisis Asam Amino}

Suryaningrum et al.(2010) dalam Astiana dkk (2016: 87) menyatakan bahwa kualitas suatu protein dapat dinilai dari kandungan asam amino yang menyusun protein tersebut. Asam amino berkontribusi terhadap kestabilan struktur helix kolagen. Komposisi asam amino kolagen kulit ikan tuna yang diekstrak menggunakan asam asetat konsentrasi 0,05 M dan 0,1 M dengan metode hidroekstraksi disajikan pada Tabel 2.

Tabel 2. Komposisi Asam Amino Kolagen Kulit Ikan Tuna Yang Diekstrak Menggunakan Asam Asetat Konsentrasi 0,05 M Dan 0,1 M

\begin{tabular}{lcc}
\hline \multicolumn{1}{r}{ Asam Amino } & $\mathbf{0 , 0 5} \mathbf{~ M}$ & $\mathbf{0 , 1 ~ M ~}$ \\
& $\mathbf{( \% )}$ & $\mathbf{( \% )}$ \\
\hline Asam Aspartat & 3.124 & 2.148 \\
Asam Glutamat & $\mathbf{7 . 1 7 4}$ & $\mathbf{7 . 1 2 8}$ \\
Serin & 3.223 & 3.217 \\
Glisin & $\mathbf{1 2 . 2 5 1}$ & $\mathbf{1 3 . 0 6 4}$ \\
Histidin & 1.365 & 1.188 \\
Arginin & $\mathbf{5 . 8 2 1}$ & $\mathbf{6 . 0 2 7}$ \\
Treonin & 1.649 & 1.776 \\
Alanin & $\mathbf{4 . 9 5 5}$ & $\mathbf{5 . 2 1 6}$ \\
Prolin & $\mathbf{4 . 8 5 7}$ & $\mathbf{4 . 6 2 1}$ \\
Tirosin & 1.781 & 1.752 \\
Valin & 2.317 & 2.451 \\
Methionin & 0.824 & 0.9 \\
Sistein & 0.944 & 0.883 \\
Isoleusin & 1.258 & 1.115 \\
Leusin & 2.118 & 2.455 \\
Phenilalanin & 1.017 & 0.754 \\
Lisin & 3.021 & 2.619 \\
\hline
\end{tabular}


Hasil analisis komposisi asam amino menunjukkan bahwa asam glutamat, glisin, arginin, alanin dan prolin merupakan lima asam amino yang paling banyak terdapat pada kolagen kulit ikan tuna metode hidroekstraksi pelarut asam asetat 0,05 $\mathrm{M}$ dan 0,1 M. Hal ini sesuai dengan pernyataan Hema et al. (2013) dalam Djailani dkk (2016: 162) menyatakan bahwa komposisi asam amino dari kolagen cenderung didominasi oleh glisin, prolin, hidroksiprolin dan alanin. Komponen asam amino yang paling banyak terkandung yaitu $1 / 3$ Glisin, $6-10 \%$ hidroksiprolin, $10-12 \%$ Prolin. Diketahui bahwa komponen prolin memberikan stabilitas termal pada kolagen. Kittiphattanabawon et al. (2005: 367) menyatakan bahwa glisin merupakan asam amino utama pembentuk kolagen yang meliputi 30\% dari total asam amino. Kolagen hidroekstraksi dari kulit ikan tuna memiliki kandungan asam glutamat, glisin, arginin, alanin dan prolin berturut-turut sebesar 7,17\%; 12,25\%; 5,82\%; 4,95\%; dan 4,86\% dari total asam amino kolagen. Hasil ini menunjukkan bahwa glisin merupakan asam amino yang paling dominan pada kolagen. Asam amino glisin pada kolagen yaitu membentuk tiga rantai alfa heliks menjadi struktur super heliks. Alanin merupakan asam amino non polar dengan gugus $\mathrm{R}$ alifatik sama seperti pada asam amino glisin. Fungsi alanin juga sama seperti glisin yakni membentuk tiga rantai alfa heliks. Djailani (2016: 163,164), menyatakan bahwa prolin merupakan asam amino yang unik dan sering disebut imino acid. Kandungan asam imino akan meningkatkan stabilitas termal dari kolagen dalam stuktur alfa heliks, energi yang dibutuhkan untuk mempertahankan struktur primer lebih rendah sehingga protein akan lebih stabil. Imino acid ini memiliki cincin pirolidina yang berfungsi menahan struktur superheliks pada kolagen. Proses hidroekstraksi memiliki komposisi asam imino yang cukup tinggi. Kandungan asam amino arginin terdeteksi menjadi ciri khas tersendiri pada kolagen metode hidroekstraksi kulit ikan tuna. Arginin merupakan asam amino semi esensial yang memiliki banyak fungsi seperti terlibat dalam produksi berbagai enzim, hormon dan protein struktural yang mendukung pelepasan hormon pertumbuhan, insulin, glukagin dan prolaktin yang merupakan komponen dari hormon vesopressin yang diproduksi oleh kelenjar hipofisis serta merupakan perkursor fisiologis senyawa nitrat, poliamina, prolin, glutamat, kreatin, agmatin dan urea. Arginin sebagai penguat imunitas, merangsang timus dan mendorong produksi limfosit sehingga dapat diaplikasikan pada penyembuhan luka bakar dan luka lainnya. Hal ini menunjukkan manfaat dari asam amino arginin sebagai agen farmasi yang dapat diaplikasikan sebagai anti-aging. (Sari dkk. (2017: 614)

\section{KESIMPULAN}

Ekstraksi kolagen menggunakan metode hidroekstraksi dengan variasi pengesktrak asam asetat 0,05 $\mathrm{M}$ dan 0,1 $\mathrm{M}$ memiliki rendemen berturut turut sebesar $1,95 \%$ dan 2,57\% dan teridentifikasi kolagen dari gugus fungsi amida A, amida B, amida I, amida II dan amida III. Hasil analisis asam amino kolagen kulit ikan tuna dengan metode hidroekstraksi menunjukkan bahwa asam glutamat, glisin, alanin dan prolin merupakan empat asam amino yang memiliki komposisi tertinggi.

\section{SARAN}

Kolagen dengan pengestrak asam asetat 0,1 M dinilai lebih baik dari segi rendemen dan mutu asam amino, meskipun masih perlu ditingkatkan saat proses hidroekstraksi yaitu mengenai perlakuan lamanya waktu hidroekstraksi saat menggunakan waterbath shakeragar supaya ektsrak kolagen yang dihasilkan bisa terekstrak lebih sempurna. Rasio aquades dan sampel saat running hidroekstraksi sebaiknya 1:1 agar efisiensi waktu karena penetrasi panas lebih cepat dan waktu di freeze dryer juga lebih cepat. 


\section{DAFTAR PUSTAKA}

Alhana., P. Suptijah, dan K. Tarman. 2015. Ekstraksi dan Karakterisasi Kolagen Dari Daging Teripang Gamma. Jurnal Pengolahan Hasil Perikanan Indonesia. 18(2): 150 - 161

Astiana, I., Nurjanah, dan T. Nurhayati. 2016. Karakteristik Kolagen Larut Asam Dari Kulit Ikan Ekor Kuning. Jurnal Pengolahan Hasil Perikanan Indonesia. 19 (1): 79 - 93

[AOAC] Association of Official Analytical Chemist. 2012. Official Methods of Analysis. Washington DC(US): Association of Official Analytical Chemist Inc.

Devi, HLNA., P. Suptijah, dan M. Nurilmala. 2017. Efektifitas Alkali dan Asam terhadap Mutu Kolagen dari Kulit Ikan Patin. Jurnal Pengolahan Hasil Perikanan Indonesia. 20(2): 255 265

Djailani, F., W.Trilaksani, dan T. Nurhayati. 2016. Optimasi Ekstraksi Dan Karakterisasi Kolagen Dari Gelembung Renang Ikan Cunang Dengan Metode asam Hidro-ekstraksi. Jurnal Pengolahan Hasil Perikanan Indonesia. 19(2): 156 - 167

Fawzya, Y.N., E.Chasanah, A.Poernomo, dan M.H. Khirzin. 2016. Isolasi Dan Karakterisasi Parsial Kolagen Dari Teripang Gamma (Stichopus variegatus). Jurnal Pascapanen dan Bioteknologi Kelautan dan Perikanan. 11(1): 91 - 100

Gadi, D.S., W.Trilaksani, dan T. Nurhayati, 2017. Histologi, Ekstraksi Dan Karakterisasi Kolagen Gelembung Renang Ikan Cunang Muarenesox talabon. Jurnal Ilmu dan Teknologi Kelautan Tropis. 9(2): 665 - 683

Kartika, I.W., W. Trilaksani, dan I Ketut M.Adnyane. 2016. Karakterisasi Kolagen Dari Limbah Gelembung Renan Ikan Cunang Hasil Ekstraksi Asam dan Hidrotermal. Jurnal Pengolahan Hasil Perikanan Indonesia. 19(3): 222 - 232

Kittiphattanabawon, P., S. Benjakul, W. Visessanguan, T. Nagai, dan M. Tanaka. 2005. Characterization Of Acid - Soluble Collagen From Skin And Bone Of Bigeye Snapper (Priachanthus tayenus). Food Chemistry. 89: 363 - 372.

Kittiphattanabawon, P., S. Benjakul, W. Visessanguan, dan F. Shahidi. 2010. Isolation and characterization of collagen from the certilages of brownbanded bamboo shark (Chiloscyllium punctatum) and blacktip shark (Carcharhinus limbatus). Food Sci Tech. 43: $792-800$

Kumar, M.H, V. Spandana, T.Poonam. 2011. Extraction And Detrmination Collagen Peptide And Its Clinical Importance From Tilapia Fish Scales (Oreochromis niloticus). International Research Journal Of Pharmacy. 2(10): 97 - 99

Krishnamoorthi, J, P. Ramasamy, V. Shanmugam, dan A. Shanmugam. 2017. Isolation And Partial Characterization Of Collagen From Outer Skin Of Sepiapharaonis (Ehrenberg, 1831) From Puducherry Coast. Biochemistry and Biophysics Reports of Journal. 39 - 45.

Mayasari, 2016. Ekstraksi Kolagen Optimum Dari Kulit Ikan Tuna (Thunnus sp.) Sebagai Antioksidan. [Skripsi]. Departemen Kimia. Fakultas MIPA - IPB

Muyonga, J.H., CGB. Cole, dan K.G. Duodu. 2004. Characterisation Of Acids Soluble Collagen From Skins Of Young And Adult Nile Perch (Lates niloticus). Food Chemistry. 85: 81-89.

Nollet L. 1996. Handbook of Food Analysis Amino. New York (US): Marcel Dekker.

Sari, E.M., M. Nurilmala, dan A. Abdullah. 2017. Profil Asam Amino dan Senyawa Bioaktif Kuda Laut Hippocampus comes. Jurnal Ilnu dan Teknologi Kelautan Tropis. 9(2): 605 - 617

Tridhar, N.A. 2016. Perbandingan Produksi Kolagen Dari Sisik Dan Tulang Ikan Gurami (Osphronemus gouramy) Secara Kimia Dan Enzimatis. Skripsi. Program Studi Teknologi Pangan Fakultas Teknik Universitas Pasundan. Bandung.

Naro, A.B, L. Sahubawa, dan N. Ekantari. 2013. Ekstraksi dan Karakterisasi Kolagen Dari Kulit Ikan Nila Hitam (Oreochromis niloticus). Jurnal Pascapanen dan Bioteknologi Kelautan dan Perikanan. 8(2): 171 - 180 
Nurilmala, M., A.M. Jacoeb, dan R.A Dzaky. 2017. Karakteristik Gelatin Kulit Ikan Tuna Sirip Kuning. Jurnal Pengolahan Hasil Perikanan Indonesia. 20(2): 340 - 350

Nurhayati, Tazwir, dan Murniyati. 2013. Ekstraksi dan Karakterisasi Kolagen Larut Asam Dari Kulit Ikan Nila (Oreochromis niloticus). Komunikasi Ringkas. Jurnal Pascapanen dan Bioteknologi Kelautan dan Perikanan. 8(1): 85 - 92

Samosir, A.S. Kristina, N. Idiawati, dan L. Destiarti. 2018. Ekstraksi Gelatin Dari Kulit Ikan Toman (Channa micropelthes) Dengan Variasi Konsentrasi Dari Asam Asetat. Jurnal Kimia Khatulistiwa. 7(3): $104-108$

Wang W, Li Z, Liu J, Wang Y, Liu S, Sun M. 2013. Comparison Between Thermal Hydrolysis And Enzymatic Proteolysis Processes For The Preparation Of Tilapia Skin Collagen Hydrolysate. Journal of Food Science. 31(1): 1 - 4.

Wulandari, 2016. Karakterisasi Fisikokimia Kolagen Yang Diisolasi Dengan Metode HidroEkstraksi Dan Stabilisasi Nanokolagen Kulit Ikan Gabus (Channa Striata). Tesis. Sekolah Pasca Sarjana Institut Pertanian Bogor. Bogor. 